It appears that many of our continental friends, anxious to contain as much as possible of their graptolite-bearing Devonian succession within the "Ludlovian", have readily agreed to Professor Holland's alternative suggestion (Bouček, Horný \& Chlupáč, 1966).

Selection of the base of the uniformis Zone as a new Siluro-Devonian boundary leaves much to be desired. Although the variations in conodonts, vertebrates and other fossil forms are being examined, the graptolites appear to provide the main support for the choice. The long-supported idea that graptolite species were relatively free from environmental influence and were, therefore, infallibly isochronous at their onset, cannot be accepted. The very absence of graptolites from the Lower Devonian marine deposits of Britain and the Rhineland indicates the existence of this influence. Biostratigraphic divisions based on quite different faunas or floras may yet provide us with more nearly equatable " time-boundaries".

The uniformis boundary would create numerous stratigraphic difficulties in this and other countries. In Britain, "Old Red Sandstone" and "Devonian " would lose their synonomity, and the Siluro-Devonian boundary would fall in the middle of a monotonous and virtually unfossiliferous strongly terrestrial succession, and would probably never be accurately distinguished. Suggestions that rocks above the Ludlow Bone Bed should be annotated "Ludlovian" are most confusing. The limits of the Ludlovian rocks in Britain are clearly defined. If the uniformis boundary is chosen, the Downtonian Stage most closely correlates with the interval between the Ludlow and the base of the uniformis Zone (Holland, 1965b).

From my own researches it seems evident that the invertebrate faunas of the Calcaire de Liévin, or the upper part of the Skala Formation as described by Kozlowski (1929), are somewhat younger than those of the Lower Downtonian marine faunas in South Wales.

The Ludlow Bone Bed cannot be correlated with many of Europe's described successions because in a large proportion of these only Devonian rocks are evident. To adjust the position of the boundary solely to provide a division in these successions seems unwarranted. Where Ludlovian rocks are present, as in the Baltic area, we are able to establish acceptable correlations within the European succession without the need for a new boundary. It would seem preferable to wait until a section is finally described in which the choice of an arbitrary datum horizon meets more widespread international agreement.

\title{
REFERENCES
}

BouČek, B., Horný, R. \& Chlupáč, I. 1966. "Silurian versus Devonian ". Acta Musei Nat. Prague. 22B, No. 2.

Holland, C. H. 1965a. The Siluro-Devonian Boundary. Geol. Mag., 102, 213-221. 1965b. Siluro-Devonian Boundary. Geol. Mag., 102, 463-4.

LaWson, J. D. \& WALMSLey, V. G. 1963. The Silurian Rocks of the Ludlow District, Shropshire. Bull. Brit. Mus. (Nat. Hist.) Geol., 8, 95-171.

Kozlowski, R. 1929. Les brachiopods gotlandiens de la Podolie Polonaise. Palaeont. polon., 1, 1-254.

White, E. I. 1950. The vertebrate faunas of the Lower Old Red Sandstone of the Welsh Borders. Bull. Brit. Mus. (Nat. Hist.) Geol., 1, 51-67.

Norwood Technical College,

KNIGHT'S HILL,

LONDON, S.E.27.

19th February, 1968.

\section{PRELIMINARY RESULTS OF A BOREHOLE AT PETROCKSTOW, NORTH DEVON}

Sir,--As part of the geological mapping of the Chulmleigh (309) Sheet, a borehole was drilled for the Institute of Geological Sciences ten miles north-north-west of Okehampton, Devon, at Tileyard Farm, Petrockstow [SS 52011041 ], elevation 197 feet A.O.D., to investigate the thickness and lithologies present in a deposit of presumed 
Oligocene age within which are several worked seams of ball clay. The Oligocene beds are contained in a downwarp between two NW-SE wrench faults belonging to the Sticklepath Fault Zone (Freshney \& Fenning, 1967). The surrounding rocks are sandstones, siltstones and shales of the Upper Carboniferous.

The borehole site was selected on the basis of both geological and geophysical investigations, the latter incorporating detailed gravity surveys which defined a northwesterly-trending negative gravity anomaly of seven milligals located across the Petrockstow deposits, where two gravity stations had previously been observed by Bott, Day $\&$ Masson-Smith (1958, p. 189). Drilling over the minimum gravity anomaly, where the outcrop of unconsolidated deposits is about one mile wide, revealed a total thickness of 2,169 feet of unconsolidated silty clays, silts, sands and quartz gravels, with subordinate brown clays, lignites and spherulitic ironstone nodules overlying Upper Carboniferous black shales, siltstones and sandstones in which the borehole terminated at 2,287 feet. From the top to about 1,200 feet silty to very silty clays predominated, while brown clays and lignites were fairly common. Below 1,200 feet silts, sands and gravels made up the bulk of the succession, with gravels near the base containing a few flints among the quartz pebbles. No animal fossils were found but worm burrowing was fairly common, especially in brown clays.

Geophysical logs were recorded in the borehole by the Schlumberger Company, and these enabled comparisons to be made between density and sonic velocity of the unconsolidated deposits and of the und rlying Upper Carboniferous strata. In Table I, the bulk density recorded by a formation density logging device has been averaged over depth intervals of 100 feet; results are listed in the second column. These values show occasional departures from the smooth increase of density with depth which might be expected to arise from compaction in a uniform deposit, and these departures can generally be related to lithological variation within the unconsolidated formations. Notable local departures from the average bulk densities given in Table I are values of $1.84 \mathrm{~g} \mathrm{~cm}^{-3}$, located between 48 and 51 feet, and $2.75 \mathrm{~g} \mathrm{~cm}^{-3}$, the latter associated with ironstone material between 1,138 and 1,140 feet. The Upper Carboniferous strata located below 2,169 feet exhibit higher bulk density values of between $2 \cdot 51$ to $2 \cdot 72 \mathrm{~g} \mathrm{~cm}^{-3}$ yielding an average value of $2 \cdot 64 \mathrm{~g} \mathrm{~cm}^{-3}$, which is in contrast to the lower densities of the

Table I.-Variation of BUlK Density AND SONIC Velocity With DePTH

$\begin{array}{cccc}\text { Depth range (feet) } & \begin{array}{c}\text { Bulk Density } \\ \left(\mathrm{g} \mathrm{cm}^{-3}\right)\end{array} & \begin{array}{c}\text { Sonic velocity } \\ \left(\text { feet }^{-1}\right)\end{array} & \begin{array}{c}\text { Sonic velocity } \\ \left(\mathrm{m} \mathrm{s}^{-1}\right)\end{array} \\ 20-100 & 2 \cdot 15 & - & - \\ 100-200 & 2 \cdot 11 & - & - \\ 200-300 & 2 \cdot 15 & - & - \\ 300-400 & 2 \cdot 19 & - & 2,070 \\ 400-500 & 2 \cdot 22 & 6,800 & 2,260 \\ 500-600 & 2 \cdot 27 & 7,400 & 2,350 \\ 600-700 & 2 \cdot 26 & 7,700 & 2,380 \\ 700-800 & 2 \cdot 25 & 7,800 & 2,410 \\ 800-900 & 2.31 & 7,900 & 2,500 \\ 900-1,000 & 2 \cdot 31 & 8,200 & 2,440 \\ 1,000-1,100 & 2 \cdot 29 & 8,000 & 2,530 \\ 1,100-1,200 & 2 \cdot 31 & 8,300 & 2,560 \\ 1,200-1,300 & 2 \cdot 25 & 8,400 & 2,620 \\ 1,300-1,400 & 2 \cdot 29 & 8,600 & 2,620 \\ 1,400-1,500 & 2 \cdot 30 & 8,600 & 2,740 \\ 1,500-1,600 & 2 \cdot 35 & 9,000 & 2,830 \\ 1,600-1,700 & 2 \cdot 28 & 9,300 & 2,830 \\ 1,700-1,800 & 2 \cdot 27 & 9,300 & 2,830 \\ 1,800-1,900 & 2 \cdot 29 & 9,300 & 2,900 \\ 1,900-2,000 & 2 \cdot 34 & 9,500 & 2,860 \\ 2,000-2,167 & 2 \cdot 28 & 9,400 & \\ 2,167-2,287 & 2 \cdot 64 & 12,500 & \\ & & & 3,810\end{array}$


overlying unconsolidated deposits. Gravity interpretation shows that the proved density distribution can account quantitatively for the Petrockstow negative gravity anomaly.

A borehole sonic log enabled the determination of average velocity for the strata encountered in the borehole. The distribution of sonic velocities with depth is given in the third column of Table I; unfortunately, no reliable values were recorded between 20 and 400 feet due to signal attenuation. Velosities in the unconsolidated deposits vary between 6,800 feet $\mathrm{s}^{-1}\left(2,070 \mathrm{~m} \mathrm{~s}^{-1}\right)$ and 9,500 feet $\mathrm{s}^{-1}\left(2,900 \mathrm{~m} \mathrm{~s}^{-1}\right)$, and are in contrast with those for the underlying Upper Carboniferous strata which exhibit an average velocity to 12,500 feet $\mathrm{s}^{-1}\left(3,810 \mathrm{~m} \mathrm{~s}^{-1}\right)$.

We thank the Director, Institute of Geological Sciences, for permission to communicate these results.

\section{REFERENCES}

Freshney, E. C. \& Fenning, P. J. 1967. The Petrockstow Basin. Proc. Ussher Soc., $1,278-280$.

BotT, M. H. P., DAY, A. A. \& MASSON-SMITH, D. 1958. The geological interpretation of gravity and magnetic surveys in Devon and Cornwall. Phil. Trans. R. Soc., A251, 161-191.

Institute of Geological Sciences,

5 Princes Gate,

LONDON, S.W.7.

P. J. Fenning.

E. C. FRESHNEY.

26th February, 1968.

\section{A MIDDLE WUURM INTERSTADIAL IN SOUTH-WEST WALES}

Sir,-A recent paper by John (Geol. Mag., 104, 630-3) unwittingly illustrates the difficulties of interpretation of derived plant material in glacial deposits; and in view of the greater use currently being made of $\mathbf{C}^{14}$ dating facilities, poses the problem of the acceptability of dates on such material.

$A \mathrm{C}^{14}$ age determination of $33,750 \pm 2,500$ years B.P. was made on derived plant fragments from Cil-maenllwyd in the kamiform Banc-y-Warren sands in South Cardiganshire. On the basis of this $\mathbf{C}^{14}$ determination (and that presented by Brown et al., 1967) John suggests that the sands in which the wood fragments lie were deposited during a "Middle Würm Interstadial", and that the local climate at this period can be inferred from derived pollen contained within the sands.

The pollen analysis presented by John does not support this latter contention, however, but is strikingly different from others of "Middle Würm" age. Many such interstadial sites are now known from both the English Midlands (Shotton, 1967) and from Holland (Van der Hammen et al., 1967) with $\mathbf{C}^{14}$ dates ranging from 29,000 to 43,000 years B.P. The environment indicated by pollen from these sites is one of shrub tundra showing periodic climatic oscillations but no well-marked re-afforestation, Salix and Betula (probably Betula nana) and occasionally Pinus, being the most prominent arboreal pollen. John's pollen analysis, however, indicates a more varied tree flora and much warmer conditions; for example, it reports Alnus, which is not found in the postglacial period before Zone VI, and Carpinus, which is not found before Zone VII. The presence of Alnus and Carpinus, together with such a high Pinus value, the latter presumably indicating relatively cool conditions, is itself puzzling (as is the absence of Betula), and suggests that the assemblage is a mixed one derived from different sources.

It is unlikely that such a floral assemblage could have existed at 33,000 years B.P. without being represented in the existing plant record of Britain or the Netherlands, especially as such a varied flora would require time to build up and decline. Neither would maritime conditions in west Wales account for such thermophilous trees at this 